PRAGATI: Journal of Indian Economy Volume 4, Issue 1, January-June 2017, pp. 43-59 doi:10.17492/pragati.v4i01.9549

\title{
An Exploratory Study of Renewable Power Sector in India
}

\author{
Shukrant Jagotra* and Deepika Kamboj**
}

\begin{abstract}
Indian power generation sector has increased by $40 \%$ from 199 GW in FY12 to over 327 GW in FY17 to become the fifth largest power generation sector globally. India 's power transmission network has also grown in sync with the generation sector to enable the evacuation of additional power produced. Renewable power has played a pivoted role in this expansion with its increased contribution in the overall generation mix from 24.5 GW in FY12 to over $57.3 \mathrm{GW}$ in FY17. This paper discusses several drivers such as government's renewable power targets, Central and state-level incentives, declining technology costs and facilitating sale of renewable power along with others that continue to outpace the barriers prevalent around poor financial condition of State Electricity Boards, challenges in renewable integration, concerns regarding sustainability of low renewable power tariffs and non-enforcement of renewable purchase obligations. The paper also an outlook of the overall renewable as well as solar and wind technology space.
\end{abstract}

Keywords: Renewable power; Energy targets; Technology costs; Power tariffs.

\subsection{Introduction}

Power sector is considered as one of the critical components to economic development of a country supporting several key sectors such as transportation, manufacturing, technology, agriculture along with others. India has the fifth-largest power generation sector globally, with a total installed capacity of $326.8 \mathrm{GW}$ (Gigawatts, as on 31 March 2017).

*Corresponding author; Research Scholar, School of Management Studies, Punjabi University, Patiala, Punjab, India. (Email id: shukrant.jagotra.ubs@gmail.com)

**Research Scholar, School of Management Studies, Punjabi University, Patiala, Punjab, India (Email id: deepikakamboj.ubs@gmail.com) 
India's power generation capacity increased at a compounded annual growth rate (CAGR) of 10.3\% from $199.9 \mathrm{GW}$ in FY12 to 327 GW in FY17 (Central Electricity Authority). India, as part of the Twelfth Five-Year Plan (2012-2017), surpassed its own capacity addition target of $88.5 \mathrm{GW}$ largely owing to strong capacity additions by private and state thermal power producers. Although India's power generation mix is changing drastically with renewable power starting to command a wider share in terms of overall generation capacity, thermal power still dominates the current generation mix. As on March 2017, thermal power has a total installed capacity of $218.3 \mathrm{GW}$ contributing $66.8 \%$ in the overall generation mix. Share of thermal power is followed by renewable power (includes small hydro power, wind power, solar power and bio-power) with an installed capacity of $57.3 \mathrm{GW}(17.5 \%)$, hydro-power with $44.5 \mathrm{GW}(13.6 \%)$, and nuclear power with $6.8 \mathrm{GW}(2.1 \%)$. The contribution of the private sector in total installed capacity has increased vastly from just $54.2 \mathrm{GW}(27.1 \%)$ in FY12 to a dominating 142.6 GW (43.6\%) in FY17. Share of private sector is followed by the falling contribution of State and the Central Government with contribution of $103.9 \mathrm{GW}$ (31.8\%, down from $42.9 \%$ in FY10) and $80.3 \mathrm{GW}$ (24.6\%, down from $29.9 \%$ in FY10) respectively (Central Electricity Authority).

Any increase in power capacity accounts for additional transmission infrastructure to enable evacuation of power as well as to maintain grid stability. India's power transmission network has also followed a similar growth trajectory as of generation capacity, and has rapidly expanded in $12^{\text {th }}$ Five-Year Plan (FYP). Transmission lines grew by a strong $30 \%$ from 257,481 circuit kilometre $(\mathrm{ckm})$ at the end of $11^{\text {th }}$ plan (FY12) to $367,851 \mathrm{ckm}$ at the end of the $12^{\text {th }}$ plan (FY17). Total transformation capacity also increased by $44.7 \%$ from 409,551 mega volt ampere (MVA) in FY12 to 740,765 MVA in FY17. Significant expansion of inter-state transmission system is under way to cater power evacuation needs of future generation projects (Ministry of Power).

\subsection{Review of Literature}

This section reviews existing literature in the area to analyse the work done and identify research gaps. Amrutha et. al. (2017) discussed the contribution of targeted policies such as feed-in-tariff (FIT), renewable purchase obligation (RPO) and renewable energy certificate (REC) in increasing the share of renewable electricity generation in the case of Karnataka State Electricity System. The study developed and analysed several scenarios using mixed-integer programming model to study the impact of these targeted policies on utilities. The results suggested that optimally managed FIT and REC schemes 
could enable utilities in reducing costs and further argued that the introduction of market-based incentives is essential to increase renewable energy penetration.

Chandel et. al. (2016) conducted an exploratory study of initiatives in renewable energy sector under the National Action Plan on Climate Change (NAPCC) in India. The study critically examined several initiatives under NAPCC in order to find implementation gaps and argued that several renewable energy sources are facing technological developmental challenges. It also highlighted the need for effective inputs on resource and technological development mechanisms for fuelling renewable energy exploitation in the country. Sen et. al. (2016) discussed the vital role of renewable power in the overall generation mix for the achievement of a variety of primary and secondary energy policy goals. With increasing share of renewable power, the paper evaluated whether India can sustain this growth and its society. It reviewed the potential renewable energy resources in Indian context while evaluating their present status, the energy demand of the country along with future consumption and production.

Jolly et. al. (2015) leveraged collective institutional entrepreneurship to study Indian wind energy across three time periods viz. 1985 to 1995, 1995 to 2003 and 2003 to 2013. The study analysed that Indian wind power development was driven by collective efforts of institutional entrepreneurs using two aggregated strategies namely supportive techno-economic \& socio-political networks and an indigenous innovation infrastructure. The paper further highlighted setbacks, controversies and tensions between various entrepreneurship groups and argued that actions must be taken for including actors who have been marginalised.

Luthra et. al. (2015) identified 28 barriers in the adoption of 'renewable and green' energy technologies by conducting an extensive literature review in Indian context and further categorised them into 7 dimensions of barriers viz. political and government issues, market, economical and financial, awareness and information, ecological and geographical, technical, cultural and behavioural barriers. It then ranked these barriers by utilizing Analytical Hierarchy Process (AHP) technique based on several experts opinions from academia and industry. Finally, sensitivity analysis was conducted to investigate the priority ranking stability of these barriers.

Kapoor et. al. (2014) focused on clean energy as one of the eight missions under NAPCC. It discussed Jawaharlal Nehru National Solar Mission (JNNSM) under which the Government of India plans to install $22 \mathrm{GW}$ of solar energy in order to realize the dream of clean energy for India by 2022. The authors attempted to outline the journey of solar energy in India from 1950s till date and highlighted the barriers and challenges that could impact the ambitious mission taken up by Government of India. 
Khare et. al. (2013) presented some of the major constraints hampering the development of renewable energy in India. It highlighted the overview, grid parity, government initiatives along with challenges and opportunities towards solar and wind energy development in India. The study further classified major obstacles towards solar and wind energy in terms of policy \& regulatory, institutional, fiscal \& financial and technological barriers. To overcome these roadblocks, the study suggested several recommendations in power policy including transmission and generation, financing of renewable energy and manufacturing of solar modules and wind turbines. Mani et. al. (2013) highlighted the need of proper policy framework to encourage the development of offshore wind farms in India. The paper conducted an exhaustive literature survey to identify 21 building blocks of a successful offshore wind energy policy initiative adopted by select European countries. It further classified these drivers under 5 broad categories viz. Government support, Fiscal and Quota based Incentives, Availability of Local Expertise, Capital for Investments and Building an Enabling Ecosystem. It argued how these factors can be leveraged by India to articulate its own offshore wind energy policy.

Schmid (2012) studied the impact of the introduction of Electricity Act 2003, Tariff Policy 2006 and the implementation of feed-in tariffs \& minimum renewable purchase obligation (RPOs) on the development of grid-connected renewable energy power in 9 Indian States using panel data over the period 2001-2009. The report concluded that the RPOs, State-level Policies, Tariff Policy 2006 and a greater participation of the private sector played a key role in promoting the development of installed capacity from renewable energy power in the selected 9 Indian states. Pandey (2012) argued that solar investors' higher interest in Rajasthan than other states is not due to its geographical \& climatic advantage but because of other determinants such as policy, infrastructure, facilitation and governance as validated by other studies. The study reviewed the initiatives responsible for accelerated development of solar energy in Rajasthan and how they can prove valuable for other regions in India and elsewhere.

Singh et. al. (2011) reviewed the current policy mechanisms, especially investment or generation-based price-driven and capacity-driven mechanisms, ranging from investment incentives for the development of renewable energy projects, feed-in tariffs, production tax incentives and tradable green certificates. The study analysed the impact of such policies in encouraging as well as expanding the development of renewable energy in Indian power sector. Singh (2009) proposed nationally tradable renewable energy credits (REC) scheme for achieving the renewable targets set by the respective State Electricity Regulatory Commissions (SERC) as part of renewable portfolio obligation. The study argued that RECs would reduce the cost of compliance and also encourage the efficient resource utilization \& investments in appropriate 
technologies. The paper also discussed regulatory developments for promotion of renewable energy in various Indian states and identified a number of issues related to regulations concerning renewable portfolio obligation.

Nouni et. al. (2008) identified potential areas in India where provision of electricity through renewable energy-based decentralized generation options can be financially more attractive as compared to extension of grid. With delivered cost of electricity from coal based thermal power plant in remote areas varying from INR3.18 to INR231.14 per unit, the paper concluded that renewable energy-based decentralized electricity supply options such as micro-hydro, dual fuel biomass gasifier systems, small wind electric generators and photovoltaic could prove financially more attractive as compared to grid extension for providing access to electricity. Dudhani et. al. (2006) highlighted the gap between peak load power demand \& availability of power at the regional level and proposed the suitability of power generation from renewable sources to fill the gap. Based on linear programming algorithm, the study formulated problem for optimum allocation of renewable energy options to meet the peak load demand at the regional levels of India. Results from linear programming indicated that the power generated by renewable resources is suitable to meet the peak load demand.

Kroeze et. al (2004) attempted to quantify the technical potential of various options to reduce emissions of greenhouse gases from the electricity sector in India in the year 2020. The study computed that there existed a technical potential to reduce the GHG emissions in 2020 by $4 \%$ to $45 \%$ depending upon the option. It computed relatively large GHG reduction potentials in case of end use efficiency improvement (45\%), replacement of coal by renewable energy and natural gas (14\% each). Other factors to reduce GHG emissions included reducing electricity losses during transmission and distribution and electrical efficiency improvement of power plants $(6 \%$ and $9 \%$ respectively).

The existing literature highlights several aspects related to renewable power in India such as initiatives taken by government under NAPCC, contribution of targeted policies in renewable power development, policy framework, initiatives such as JNNSM, drivers, opportunities and barriers along with others. However various factors including increasing contribution of renewable, technological advancements, changing economics of raw materials, varying government policies and incentives across states and time point towards the dynamic nature of all these aspects. Thus there is a need to revisit some of these aspects in order to achieve a more conducive business environment for renewable power development in the country. 


\subsection{Indian Renewable Power Market}

India has a vast potential for renewable power generation. India has a massive $748 \mathrm{GW}$ of solar potential with states such as Jammu \& Kashmir, Madhya Pradesh, Maharashtra and Gujarat cumulatively accounting to $380 \mathrm{GW}$ of this potential in the country. Similarly, India has an enormous wind power potential of $302 \mathrm{GW}$ (at 100 meters above ground level). States such as Andhra Pradesh, Gujarat, Karnataka, Maharashtra and Tamil Nadu possess over $85 \%$ of the total wind power potential in the country (National Institute of Solar Energy).

The contribution of renewable power in the overall power generation mix has increased considerably from 24.5 GW in FY12 to over 57.3 GW in FY17. Renewable power generally comprises hydro, solar, wind, and bio-power. However, the Central Electricity Authority of India only includes small-hydro power as part of renewable energy sources (RES) apart from solar, wind and bio-power and classifies large-hydro and nuclear power as sources other than renewable power. At present, non-hydro renewable power contributes $17 \%$ in the overall generation mix. Wind power dominates the renewable generation mix with an installed capacity and share of 32,280 MW and $56.5 \%$ respectively followed by solar power with 12,289 MW (21.4\%), bio-power and small-hydro power with 8,312 MW (14.5\%) and 4,380 MW (7.6\%) respectively (Central Electricity Authority).

Owing to government's increasing impetus towards renewable power, two of the largest renewable technologies viz. wind and solar power are expected to play a wider role in the overall renewable energy mix going forward. As per the 2016 National Draft Policy, the government is looking to achieve $523 \mathrm{GW}$ of installed capacity by FY22 of which $175 \mathrm{GW}$ shall come from renewable energy sources. In other words, renewable power shall command $33 \%$ share in the overall generation mix by 2022 , which is close to twice its current share of $17 \%$. Figure 1 shows the power generation mix by 2022 as per the National Draft Policy (Central Electricity Authority).

\subsection{Drivers for Renewable Power Growth}

\subsection{Government's ambitious renewable energy target}

Renewable power growth gained momentum in the $12^{\text {th }}$ Five Year Plan. To ensure that this growth remains steady, the government has set a target to achieve 175 GW of renewable power by 2022 . This $175 \mathrm{GW}$ of renewable installed capacity includes $100 \mathrm{GW}$ (40GW rooftop, 60GW ground-mounted), 60GW, 10GW and 5GW of solar, wind, biomass and small-hydro power respectively. Besides a cumulative national target, 
the government has also furnished state-wise renewable power targets. With reference to solar, states such as Maharashtra, Uttar Pradesh, Andhra Pradesh, Tamil Nadu and Gujarat are cumulatively expected to contribute almost $50 \%$ of the overall solar installed capacity target of $100 \mathrm{GW}$ by 2022. Similarly with reference to wind, states such as Tamil Nadu, Gujarat, Rajasthan, Andhra Pradesh and Maharashtra are cumulatively expected to achieve as much as three-fourth of the overall installed wind capacity target of $60 \mathrm{GW}$ by 2022 (Ministry of New and Renewable Energy).

Figure 1: Power Generation Mix in 2022 (in GW)

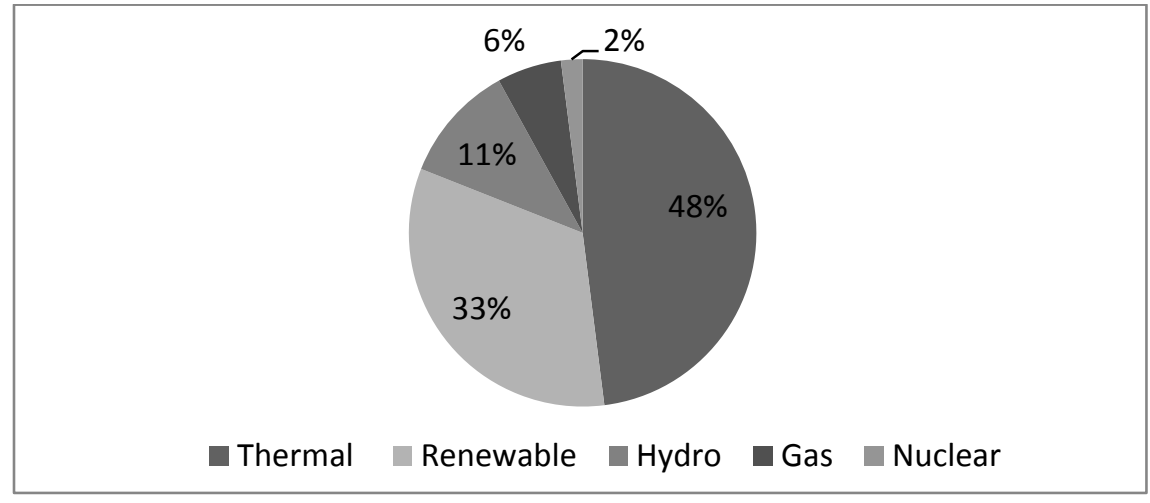

Source: Central Electricity Authority

Besides above, Government of India in its submission to the United Nations Frame Work Convention on Climate Change on Intended Nationally Determined Contribution (INDC) stated that the country will achieve $40 \%$ cumulative electric power capacity from non-fossil fuel based energy resources by 2030 by leveraging transfer of technology and low-cost international finance including from Green Climate Fund.

\subsection{Declining technological costs}

Falling costs of key components such as solar panels as well as wind turbines coupled with improvements in efficiency are enabling project developers to reduce project costs significantly. Owing to falling project costs, project developers are able to bid low and highly competitive power tariffs resulting in higher penetration of renewable power in the country. For instance, prices for crystalline silicon module have dropped by $30 \%$ over the past year alone. Further, advancements in wind turbine technology such as increase in rotor diameter and hug height have resulted in improved efficiency.

This combination has helped in reducing the power tariffs considerably. In April 2017, NTPC Limited's (formerly known as National Thermal Power Corporation 
Limited) 250 Megawatt solar project at Kadapa in Andhra Pradesh was awarded at as low as INR3.15/kWh (kilowatt-hour or 1 unit) to the Indian arm of French clean energy firm Solairedirect. Similarly in February 2017, Solar Energy Corporation of India (evaluator of first of-a-kind wind power auction under competitive bidding mechanism) received bids to supply wind power for just INR3.46/kWh (Solar Energy Corporation of India).

\subsection{Central and state incentives}

The government is offering several incentives to lower the cost of renewable power development in the country. These incentives include central financial assistance, income tax holiday, appreciated depreciation, full excise duty exemption and concessional customs import duty along with others. Incentives by the Central government for developing solar power include central financial assistance (CFA). The government offers CFA for grid connected solar rooftop by up to $30 \%$ of benchmark cost for general category states \& UTs and up to $70 \%$ of benchmark cost for special category (special category states include North Eastern States including Sikkim, Uttarakhand, Himachal Pradesh, Jammu \& Kashmir, Lakshadweep and Andaman \& Nicobar Islands). In addition to CFA, Ministry of New and Renewable Energy (MNRE) also offers achievement-linked incentive for grid-connected rooftop and small solar power plants for government sector buildings (Ministry of New and Renewable Energy).

State governments are also playing an active role in promoting renewable power development in the country. Several states have made crucial policy changes such as feed in tariff to ensure sale of renewable power and rate concessions in land allocation along with others. Table 1 highlights some of the state-level policies for developing wind power.

\subsection{Guidelines and policies to develop solar and wind technologies}

The government has prepared several guidelines and policies to boost the development of renewable projects as well as to enable the project developers to understand central incentives, new upcoming technologies along with other modern and efficient project development activities. Some of them are highlighted as under:

- In 2016, MNRE released the "Policy for Repowering of the Wind Power Projects," under which several incentives (fiscal, financial and additional interest rate rebate of $0.25 \%$ ) along with state support shall be offered to wind turbine generators of capacity $1 \mathrm{MW}$ and below.

- MNRE released "Guidelines for Development of Onshore Wind Power Projects," to facilitate the development of wind power projects in an efficient, cost effective and 
environment friendly manner taking into account the requirements of project developers, state and national imperatives in 2016.

- In 2016, MNRE prepared draft national "Wind-Solar Hybrid Policy" as several studies reveal that hybridisation of solar and wind technologies would help in minimising the variability.

Table 1: State-level Power Policies for Wind Power Development

\begin{tabular}{|l|l|l|l|}
\hline Parameters & Gujarat & Rajasthan & Karnataka \\
\hline Feed in tariff & INR4.15/Unit & INR5.14- 5.74/Unit & INR4.5/Unit \\
\hline $\begin{array}{l}\text { Land } \\
\text { allocation }\end{array}$ & $\begin{array}{l}\text { Wind power can be set } \\
\text { up on private land, or } \\
\text { waste land, or Gujarat } \\
\text { Energy Development } \\
\text { Agency land as per } \\
\text { availability }\end{array}$ & $\begin{array}{l}\text { Government land to be } \\
\text { allotted at a } \\
\text { concessional rate of } \\
10 \%\end{array}$ & $\begin{array}{l}\text { Government to provide } \\
\text { land for development } \\
\text { on 30 years lease as per } \\
\text { the prime lending rate } \\
\text { over current market } \\
\text { price }\end{array}$ \\
\hline \multirow{2}{*}{$\begin{array}{l}\text { Other } \\
\text { incentives }\end{array}$} & $\begin{array}{l}\text { Wind power exempted } \\
\text { from electricity duty. } \\
\text { Transmission of wind } \\
\text { power for third-party } \\
\text { sale and captive use } \\
\text { exempted from cross- } \\
\text { subsidy charges }\end{array}$ & $\begin{array}{l}\text { Wind energy consumed } \\
\text { own captive use is } \\
\text { exempted from } \\
\text { payment of electricity } \\
\text { duty }\end{array}$ & $\begin{array}{l}\text { Renewable energy } \\
\text { projects to fall under } \\
\text { industrial incentive } \\
\text { schemes }\end{array}$ \\
\hline
\end{tabular}

\subsection{Facilitating sale of renewable power}

The government has set several mechanisms such as renewable energy certificate (REC) and renewable purchase obligations (RPO) to facilitate the sale of renewable power in the country. RPO mandates that all electricity distribution licensees should purchase or produce a minimum specified quantity of their requirements from renewable energy sources. REC is a market-based mechanism to promote renewable energy and facilitate compliance of RPOs. It aims to address the mismatch between availability of renewable energy resources in the states and the requirement of the obligated entities to meet their RPO. The state electricity regulatory commissions fix the minimum RPO for the states.

In March 2017, the Central Electricity Regulatory Commission (CERC) has proposed to decrease the floor prices of renewable energy certificates (RECs), making it 
easier for the state distribution companies to meet their RPO obligations. RPO targets of some of the states are shown in Figure 2.

Figure 2: RPO targets for key states in FY16

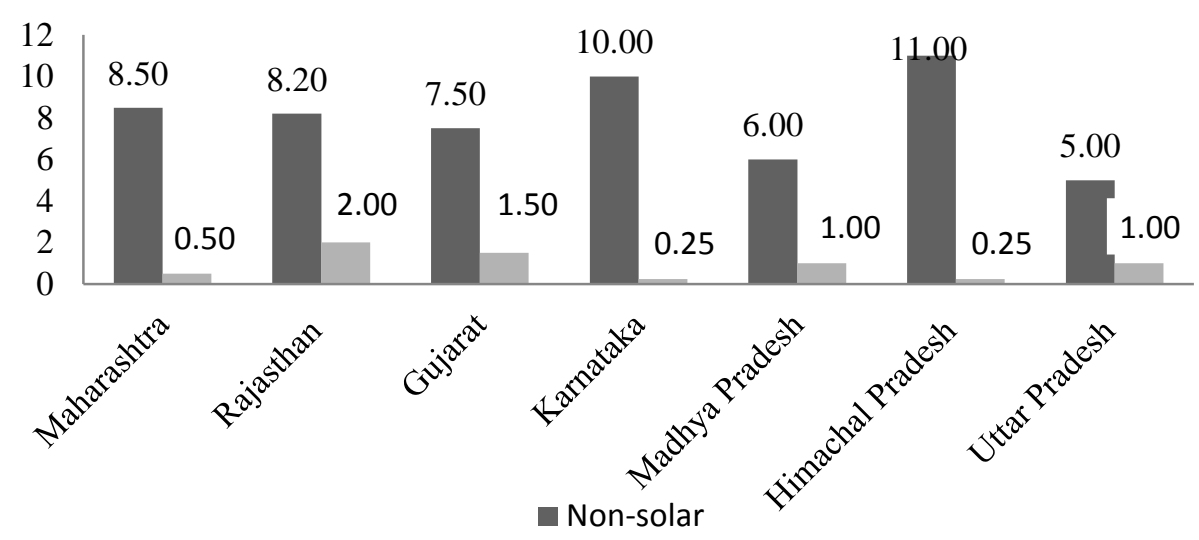

Source: Ministry of New and Renewable Energy

\subsection{Barriers against Renewable Power}

\subsection{Poor financial condition of distribution companies}

Weak financial condition of most State Electricity Boards (SEBs) has resulted in several issues for power producers such as defaults and reduced off-take from SEBs. MNRE, for instance, is in talks with several distribution utilities to clear the dues of around INR30 billion towards various wind power generation companies. This poor financial health is affecting all parts of the power value chain viz. generation, transmission and distribution.

Considerations: To tackle this growing concern, the government has launched the Ujwal DISCOM Assurance Yojana (UDAY) scheme to enable financial turnaround of these ailing SEBs. With State government assuming $75 \%$ of the distribution company's debt, the scheme aims to reduce the interest cost from the current levels of $14 \%-15 \%$ to $8 \%$ 9\%. As on March 2017, 16 states and union territories have signed memorandum of understanding (MoU) for participating in UDAY. The scheme is estimated to account for capital savings worth US\$1.8billion for public sector banks (Ministry of Power).

\subsection{Challenges in renewable power integration}

Renewable power generation differs from the conventional power generation where power produced is constant throughout the day and places of power generation are 
limited. In case of renewable power, the amount of power generated fluctuates throughout the day. With many discrete power-producing units, integration of all these units in the grid is a tedious and expensive task that can adversely impact the stability of grid if not conducted optimally.

Considerations: Many International Financial Institutions have offered to support the ongoing efforts of renewable integration in the country. For instance, World Bank has recently announced its decision to provide more than US\$1billion for supporting India's ambitious initiatives to expand solar generation projects (projects include solar rooftop, infrastructure for solar parks, innovative solar and hybrid technologies, and transmission lines). Asian Development Bank (ADB) has also agreed to provide US $\$ 1$ billion to Power Grid Corporation of India (PGCIL), for setting up transmission lines dedicated to carrying electricity from renewable energy projects (Power Grid Corporation of India).

\subsection{Low project feasibility with rapidly falling tariffs}

Shift from feed-in-tariff (FITs), where tariffs are pre-agreed between the developer and government, towards competitive bidding mechanism has had a downward pressure on tariff prices. Power tariff for both the solar as well as wind power have witnessed a falling trajectory. For instance, a recent wind power auction (where mechanism has just changed from FITs to competitive bidding) saw wind power tariff fall to INR3.46/unit from the prevalent rates of INR5/unit through FITs. This aggressive bidding and the rapid fall in tariff prices in India's solar power auctions have the potential to jeopardise the economic feasibility of the project pipeline in long run as it squeezes the returns on offer for the project developer and may result in project cancellations if the price is too low to cover costs.

Although initially (and even today in some cases) viewed as a positive sign for the prospects of India's solar and wind sector, the lowering of prices at such a rapid rate has the potential to knock investor confidence in the market if the developers fail to deliver the project on time or worse if the project fails to surpass the planning phase. The risk is particularly pertinent for project financiers, and could lead to a tightening of available funding for the Indian solar and wind sector.

Considerations: To maintain economic feasibility in the long run, project developers should be able to forecast both positive and negative developments in the solar/wind/other renewable technology as well as overall power sector along with key macroeconomic indicators. As forecasting such developments might be difficult to achieve in terms of accuracy, a project developer can utilise the popularly used sensitivity analysis to build optimistic, most-likely and pessimistic cases and ensuring 
54 | PRAGATI: Journal of Indian Economy, Volume 4, Issue 1, January-June 2017

project feasibility or profitability in all. The government in turn can also invite such analysis from project developers as a compliance measure.

\subsection{Non-enforcement of renewable purchase obligation}

Although RPOs is a major step towards ensuring sale of renewable power, several states have not been able to fulfil their mandated RPO. The case is not limited to the states that are low on renewable energy potential (and thus have to buy renewable power from other states surplus in renewable power), even the renewable energy-rich states such as Gujarat, Rajasthan and Andhra Pradesh defaulted on their targets as well. Non-enforcement of RPOs is leading to losses for several of the solar and wind energy producers throughout the country as they are unable to produce enough power to even arrive at the breakeven point. For instance, 25 states and union territories have failed to achieve their specified solar-RPO targets for FY17. As on March 2017, solar-RPO deficit stands at a staggering 2,034 MW (close to 64\% target deficit).

Considerations: Stricter norms, penalties, better transmission and infrastructure along with payments guarantee are needed to make states and union territories adhere to the RPOs mandate.

\subsection{Recent Tenders}

\subsection{Wind power}

In 2016, MNRE released guidelines for setting up of 1,000 MW wind power projects connected to the inter-state transmission system (ISTS). Key objectives of the scheme were to encourage competitive pricing, transparency and also helping low wind potential states to meet their non-solar RPO obligation.

Based on the above guidelines, Solar Energy Corporation of India (SECI) conducted first onshore wind auction in February 2017. SECI received bids to supply wind power for INR3.46/KWh, which is significantly lower than the prevalent FITs across most states. Mytrah Energy, Sembcorp Green Infra, Inox Wind Infrastructure Services and Ostro Kutch Wind were awarded $250 \mathrm{MW}$ each, while Adani Green Energy was awarded 50 MW (Solar Energy Corporation of India; Ministry of New and Renewable Energy). Table 2 presents a summary of recent wind power auction.

The government is also planning to auction $4 \mathrm{GW}$ wind projects in FY18 in several phases. MNRE has also published draft guidelines for wind power auctions to seek comments and suggestions on the proposed rules. 
Table 2: Summary of Recent Wind Power Auction

\begin{tabular}{|l|l|}
\hline Name of tender & 1,000 MW ISTS connected wind power projects \\
\hline Launch Date & 2017 \\
\hline Evaluator & Solar Energy Corporation of India \\
\hline \multirow{3}{*}{$\begin{array}{l}\text { Procurement } \\
\text { method }\end{array}$} & $\begin{array}{l}\text { Request for Selection (RfS) for development of wind power } \\
\text { - Assessment of participants by SECI for fulfillment of technical } \\
\text { and financial criteria }\end{array}$ \\
$\begin{array}{ll}\text { - Bidders quote the capacity and tariff } \\
\text { - Selection of bidders through open and transparent competitive } \\
\text { bidding process followed by e-reverse auction }\end{array}$ \\
$\begin{array}{ll}\text { - Selection of trading company followed by PPA with selected } \\
\text { bidder and back-to-back PSA with buying entities at a pooled } \\
\text { price of the total bids selected }\end{array}$ \\
\hline Incentives & $\begin{array}{l}\text { Bidders eligible for fiscal and financial incentives from } \\
\text { central and state governments }\end{array}$ \\
\hline Government support & $\begin{array}{l}\text { MNRE will set empowered committee to facilitate smooth } \\
\text { implementation of the scheme }\end{array}$ \\
\hline
\end{tabular}

Source: MNRE and News Articles

\subsection{Solar power}

In contrast to other larger solar markets around the world (such as China, US, Germany, Japan etc.) that have been allocating projects on a preferential basis by offering attractive feed-in-tariffs (FITs), India has adopted the process of allocating utility scale solar projects through competitive tender process. The competitive bidding mechanism along with government's plan to achieve $100 \mathrm{GW}$ solar power by 2022 have helped in increasing the pace of solar tenders in the country.

Solar tariffs fell to a record low with the latest auction of 750 MW REWA solar park in Madhya Pradesh. The contracts were awarded to Mahindra Renewables, Acme Solar and Sweden's Solenergi Power for INR2.979/kWh, INR2.970/kWh and INR2.974/kWh respectively for 250 MW capacity each (Solar Energy Corporation of India; Ministry of New and Renewable Energy). Table 3 presents a summary of recent solar power auction.

Between July 2015 and December 2016, India allocated 15.9 GW of solar projects of which power purchase agreement (PPA) based tenders comprises of 82\% (13.1 GW) and rest for engineering procurement and construction (EPC). 
56 | PRAGATI: Journal of Indian Economy, Volume 4, Issue 1, January-June 2017

Table 3: Summary of Recent Solar Power Auction

\begin{tabular}{|c|c|}
\hline Name of tender & 750 MW REWA solar park in Madhya Pradesh \\
\hline Launch Date & 2017 \\
\hline Evaluator & $\begin{array}{l}\text { Rewa Ultra Mega Solar Limited, MNRE, Madhya Pradesh } \\
\text { Urja Vikas Nigam Limited (MPUVN) }\end{array}$ \\
\hline $\begin{array}{l}\text { Procurement } \\
\text { method }\end{array}$ & $\begin{array}{l}\text { - } \text { Phase I - tariff based Techno Commercial Bid } \\
\text { - Phase II Tariff based reverse auctioning } \\
\text { - Auction sets out total target amount to be procured } \\
\text { - Bidders quote the capacity they want } \\
\text { - PPAs are entered into with Delhi Metro Rail Corporation or } \\
\text { Madhya Pradesh Power Management Company }\end{array}$ \\
\hline Incentives & $\begin{array}{l}\text { Government to pay a compensation if sufficient grid is not } \\
\text { available for transmission of power from the project }\end{array}$ \\
\hline Land & $\begin{array}{l}\text { Solar park bids have land already acquired by the } \\
\text { government while in other cases project developer is } \\
\text { required to procure land }\end{array}$ \\
\hline
\end{tabular}

Source: MNRE and News Articles

\subsection{Outlook}

Strong economic growth, increased per capita consumption, favorable policies, electrification of un-electrified villages/rural households and the continuing pace of urbanization are expected to drive electricity installation in India at a CAGR of 7.5\% from $327 \mathrm{GW}$ in FY17 to reach $471 \mathrm{GW}$ in 2022. Renewable power is expected to command a stronger share in the overall installed capacity going forward. Installation of non-hydro renewable power is expected to increase to $93 \mathrm{GW}$ by 2022. Solar and wind shall continue to dominate the overall renewable power generation mix going forward. Figure 3 forecasts yearly capacity addition for solar and wind technologies till 2022 (Business Monitor International).

\subsection{Conclusion and Implications}

The research paper attempted to review the current and future scenario of Indian renewable power market in terms of overview, drivers, barriers, considerations for government and project developers, recent solar and wind tenders as well as outlook through secondary and qualitative research. The study highlighted India's growth in power sector (both generation and transmission) in the $12^{\text {th }}$ Five Year Plan and its expected future growth of over $40 \%$ in terms of installed capacity to reach $471 \mathrm{GW}$ by 
2022. With government's ambitious target to achieving $175 \mathrm{GW}$ of renewable installed capacity by 2022 , renewable power is expected to drive a major chunk of this growth. The paper discussed the dominance of drivers over barriers (along with considerations to tackle these barriers) to increase the penetration of renewable power in the market as well as to lower the power tariffs as exemplified in the recent auctions where wind and solar tariffs fell below INR3.5/unit and INR3.0/unit respectively. It is without debate that renewable power shall continue to be the next big thing in the Indian power sector with an expected installed capacity of $93 \mathrm{GW}$ by 2022 .

Figure 3: Solar and wind power forecast (in GW)

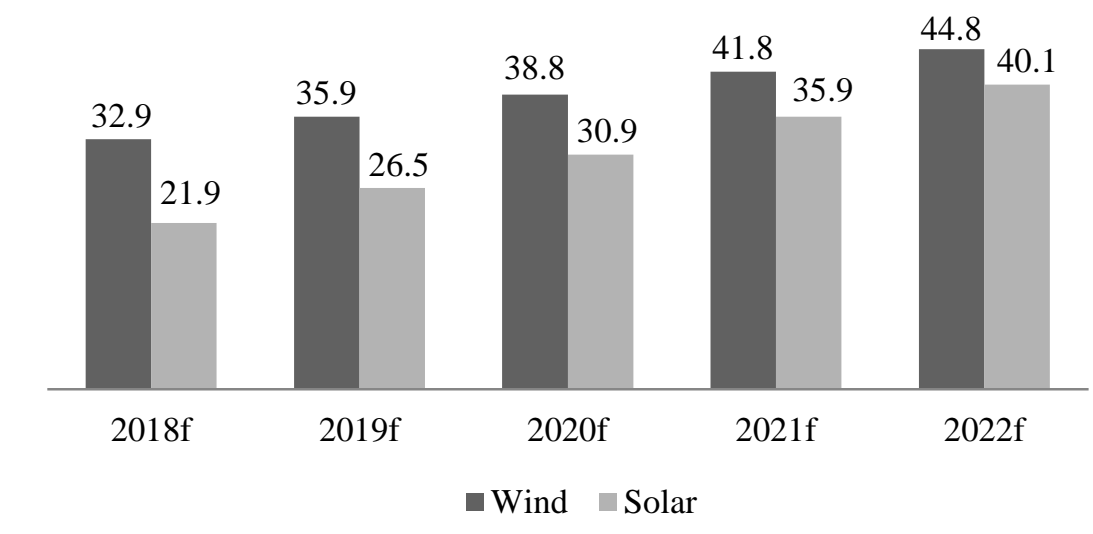

Source: Business Monitor International

\subsection{Implications}

The sections discussed in the paper have implications for the investors, project developers, policy-makers and the government. Apart from gaining understanding about the market, the research paper demonstrates the massive opportunity for investors as well as project developers in the Indian renewable power space. It exemplifies the same by highlighting some of the investor-friendly central as well as state level policies \& incentives along with strong participation in some of the recently conducted solar and wind power auctions. The barriers against renewable power growth also have intense implications for all stakeholders. For investors and project developers, they would be a critical factor in calculating the feasible power tariffs while for the government and policy-makers these barriers point towards the need for more reforms ensuring market attractiveness. 
58 | PRAGATI: Journal of Indian Economy, Volume 4, Issue 1, January-June 2017

\section{References}

Amrutha, A.A., Balachandra, P., \& Mathirajan, M. (2017). Role of targeted policies in mainstreaming renewable energy in a resource constrained electricity system: A case study of Karnataka electricity system in India. Energy Policy, 106, 48-58.

Chandel, S.S., Shrivastva, R., Sharma, V. \& Ramasamy, P. (2016). Overview of the initiatives in renewable energy sector under the national action plan on climate change in India. Renewable and Sustainable Energy Reviews, 54, 866-873.

Draft National Electricity Plan Volume I. (2016, December). Retrieved from http://www.cea.nic.in/reports/committee/nep/nep_dec.pdf

Dudhani, S., Sinha, A.K., \& Inamdar, S.S. (2006). Renewable energy sources for peak load demand management in India. International Journal of Electrical Power \& Energy Systems, 28(6), 396-400.

Growth in Transmission Sector. (2017, March). Retrieved from http://powermin.nic.in/ sites/default/files/uploads/Growth_in_Transmission_sector_IRTC_English.pdf

Jolly, S., \& Raven, R.P.J.M. (2015). Collective institutional entrepreneurship and contestations in wind energy in India. Renewable and Sustainable Energy Reviews, 42, 999-1011.

Kapoor, K., Pandey, K.K., Jain, A.K., \& Nandan, A. (2014). Evolution of solar energy in India: A review. Renewable and Sustainable Energy Reviews, 40, 475-487.

Khare, V., Nema, S. \& Baredar, P. (2013). Status of solar wind renewable energy in India. Renewable and Sustainable Energy Reviews, 27, 1-10.

Kroeze, C., Vlasblom, J., Gupta, J., Boudri, C., \& Blok, K. (2004). The power sector in China and India: Greenhouse gas emissions reduction potential and scenarios for 19902020. Energy Policy, 32(1), 55-76.

Luthra, S., Kumar, S., Garg, D. \& Haleem, A. (2015). Barriers to renewable/sustainable energy technologies adoption: Indian perspective. Renewable and Sustainable Energy Reviews, 41, 762-776. 
Mani, S., \& Dhingra, T. (2013). Offshore wind energy policy for India - Key factors to be considered. Energy Policy, 56, 672-683.

Nagamani, C., Ilango, G.S., Reddy, M., Rani, M. \& Lakaparampil, Z.V. (2015). Renewable power generation Indian scenario: A review. Journal Electric Power Components and Systems, 43(8-10), 1205-1213.

Nouni, M.R., Mullick, S.C., \& Kandpal, T.C. (2008). Providing electricity access to remote areas in India: An approach towards identifying potential areas for decentralized electricity supply. Renewable and Sustainable Energy Reviews, 12(5), 1187-1220.

Pandey, S., Singh, V.S., Gangwar, N.P., Vijayvergia, M.M., Prakash, C., Pandey, \& D.N. (2012). Determinants of success for promoting solar energy in Rajasthan, India. Renewable and Sustainable Energy Reviews, 16(6), 3593-3598.

Schmid, G. (2012). The development of renewable energy power in India: Which policies have been effective?. Energy Policy, 45, 317-326.

Sen, S., Ganguly, S., Das, A., Sen, J., \& Dey, S. (2016). Renewable energy scenario in India: Opportunities and challenges. Journal of African Earth Sciences, 122, 25-31.

Singh, A. (2009). A market for renewable energy credits in the Indian power sector. Renewable and Sustainable Energy Reviews, 13(3), 643-652.

Singh, R., Sood, Y.R. (2011). Current status and analysis of renewable promotional policies in Indian restructured power sector - A review. Renewable and Sustainable Energy Reviews, 15(1), 657-664.

Twelfth Five Year Plan, Economic Sectors, Volume II. (2013). Retrieved from http://planningcommission.gov.in/plans/planrel/12thplan/pdf/12fyp_vol2.pdf 